\title{
Lowe syndrome: Case report of a patient with a novel mutation in the $O C R L$ gene
}

*Grace Angeline Malarnangai Kularatnam ${ }^{1}$, Vindya Subasinghe ${ }^{2}$, Dilanthi Hewa Warawitage ${ }^{3}$, Kandana Liyanage Subhashinie Jayasena ${ }^{3}$, Florian Recker ${ }^{4}$, Eresha Anandanie Jasinge ${ }^{3}$, Samantha Waidyanatha ${ }^{3}$, Michael Ludwig ${ }^{4}$

Sri Lanka Journal of Child Health, 2017; 46(3): 281-283

DOI: http://dx.doi.org/10.4038/sljch.v46i3.8334

(Key words: Lowe syndrome, OCRL gene, oculocerebrorenal syndrome, congenital cataract)

\section{Introduction}

The oculocerebrorenal (OCRL) syndrome of Lowe is an X linked, multisystem disorder characterised by a triad of abnormalities in the eyes, the nervous system and the renal tubules ${ }^{1}$. It is caused by a mutation in the OCRL gene which encodes an inositol polyphosphate 5-phosphatase. This enzyme has been detected on vesicular structures of the endosomal system and the Golgi complex, and plays a main role in cellular metabolism. The deficiency of this enzyme impairs the maturation of polarizing epithelium in neurons and glia, renal proximal tubule and lens ${ }^{2}$. Prevalence of this syndrome has been estimated as 1 in $500,000^{3}$.

\section{Case report}

This baby boy was born of a non-consanguineous marriage in January 2013 at the Base Hospital, Kahawatta and bilateral cataracts were detected at birth. On the 4th day of life, baby was referred to the Eye Surgeon, Lady Ridgeway Hospital (LRH), Colombo. He underwent bilateral trabeculectomy at the age of 2 months. At the age of 1 week, baby was referred to the Department of Chemical Pathology for necessary biochemical investigations of cataract by the eye unit. There is a history of delayed milestones. His family tree (Figure 1) revealed his maternal cousin to share the clinical features.

On physical examination, his weight was $6.2 \mathrm{~kg}$ less than - 3SD), height was $64 \mathrm{~cm}$ (less than -3 SD) and head circumference was $45 \mathrm{~cm}\left(10^{\text {th }}\right.$

${ }^{1}$ District General Hospital Matara, Sri Lanka,

${ }^{1}$ District General Hospital Negombo, Sri Lanka,

${ }^{3}$ Lady Ridgeway Hospital Colombo, Sri Lanka,

${ }^{4}$ University of Bonn, Bonn, Germany

*Correspondence: cecilselvadurai@yahoo.com

(Received on 19 April 2016: Accepted after revision on 20 May 2016)

The authors declare that there are no conflicts of interest

Personal funding was used for this project.

Open Access Article published under the Creative

Commons Attribution CC-BY License. centile). He had frontal bossing, flat nasal bridge, upward nystagmus, microcephaly, hypermobility of joints, hypotonia, severe global developmental delay and failure to thrive (Figure 2).

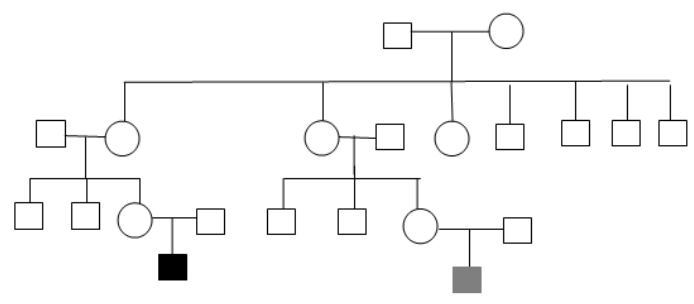

Lowe's syndrome
Probably Lowe's syndrome

Figure 1: Family tree

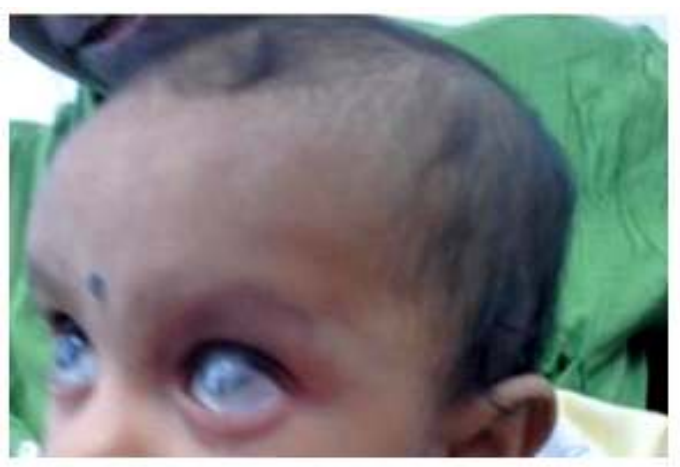

Figure 2: Showing microcephaly, frontal bossing, flat nasal bridge and cataract

*Permission given by parents to publish photograph

The clinical laboratory investigations showed hyperchloraemic metabolic acidosis with normal serum creatinine. Serum alkaline phosphatase, fasting phosphate, tubular reabsorption of phosphate and corrected calcium were $717 \mathrm{U} / \mathrm{L}(80$ - 480), $1.06 \mathrm{mmol} / \mathrm{L}$ (1.45 - 2.16), 84\% (> 85\%) and $2.61 \mathrm{mmol} / \mathrm{L}(2.2-2.7)$ respectively. Serum creatine kinase, lactate dehydrogenase and aspartate aminotransferase were elevated. 25hydroxy vitamin D level was $46.2 \mathrm{nmol} / \mathrm{L}$ (deficient $\leq 50)$ and parathormone $(\mathrm{PTH})$ level was 
$66.5 \mathrm{pg} / \mathrm{ml}(10-65)$. His urine investigations are summarised in table 1. X-ray wrist showed delayed bone age. Ultra sound scan of the brain was normal.

Table 1: Urine biochemical investigations

\begin{tabular}{|l|l|}
\hline \multicolumn{1}{|c|}{ Type of test } & Result (ref. range) \\
\hline Spot test & $7.3(6-6.5)$ \\
pH & \\
Uric acid: creatinine ratio & \\
$(\mathrm{mmol} / \mathrm{mmol})$ & $1.64(0.5-1.4)$ \\
Alanine $(\mu \mathrm{mol} / \mathrm{L})$ & $7076(767-6090)$ \\
Citrulline $(\mu \mathrm{mol} / \mathrm{L})$ & $803(22-181)$ \\
Lysine $(\mu \mathrm{mol} / \mathrm{L})$ & $2760(189-850)$ \\
Cystine & Positive \\
Tyrosine & Positive \\
Clinistix test for glucose & Negative \\
\hline 24 hour excretion & $92(<4)$ \\
Protein $\left(\mathrm{mg} / \mathrm{m}^{2} / \mathrm{hour}\right)$ & $0.12(<0.1)$ \\
Calcium $(\mathrm{mmol} / \mathrm{kg} /$ day) & $0.7(0.48-0.64)$ \\
Phosphate $(\mathrm{mmol} / \mathrm{kg} /$ day) & \\
\hline
\end{tabular}

He was treated with Joule's solution and Polycitra. The clinical diagnosis of Lowe syndrome was confirmed by DNA analysis. This revealed a hemizygous mutation c. $1427 \mathrm{C}>\mathrm{T}$ (p.Thr476Ile) in exon 14 and carriership was confirmed in the mother. Slit lamp examination of eyes of his mother did not reveal any abnormalities and her renal tubular functions were normal.

\section{Discussion}

Patients with OCRL syndrome, typically present in infancy with congenital bilateral cataract, growth failure and mental retardation. Cataract manifests early in embryogenesis. Congenital or childhood glaucoma has been observed in $50 \%$ of Lowe syndrome patients ${ }^{4}$. Neurologic manifestations include seizures, repetitive behaviour, intellectual disability and variable degree of mental retardation. Renal tubular dysfunctions include low molecular weight proteinuria, albuminuria, aminoaciduria, hypercalciuria and phosphaturia which may lead to chronic renal failure ${ }^{5}$.

Our patient was clinically diagnosed on the basis of typical occulocerebrorenal manifestations. Impaired proximal tubular reabsorption led to generalised aminoaciduria, proteinuria, phosphaturia, hyperuricosuria and metabolic acidosis. He did not have glycosuria which is consistent with other reported cases of Lowe and indicates selective proximal dysfunction in Lowe syndrome patients ${ }^{2}$. Our patient also had vitamin D deficiency. Usually Lowe patients develop vitamin $\mathrm{D}$ dependent rickets due to impaired activation of 1-alpha hydroxylase with normal 25-hydroxy vitamin $\mathrm{D}$ level ${ }^{6}$. In our case vitamin $\mathrm{D}$ deficiency led to high PTH and ALP levels. X-rays did not show evidence of rickets.
Hyperphosphaturia and metabolic acidosis due to bicarbonate loss are part of the proximal tubulopathy of Lowe syndrome or result from PTH action on renal tubules. Hypercalciuria may be a manifestation of either tubulopathy or vitamin D deficiency. Though our patient had hypercalciuria, there was no radiological evidence of urolithiasis or nephrocalcinosis often reported in OCRL patients ${ }^{7}$. Severe hypotonia is reported in the literature ${ }^{3}$ and our patient also had hypotonia with elevated CK, $\mathrm{LDH}$ and AST despite of normal liver function. Elevation of these enzymes could be due to muscle involvement. According to the literature carrier mothers with a mild phenotype developed aminoaciduria following ornithine loading ${ }^{8}$ and often show eye lesions by slit lamp examination ${ }^{9}$. We could not perform ornithine loading test but eye examination did not detect any abnormalities. As she is a carrier, she has $25 \%$ of possibility of having an affected boy and $25 \%$ of possibility of having a carrier girl in future pregnancies. His 5year-old cousin was clinically diagnosed as Lowe syndrome and is on treatment however we could not perform genetic analysis on him.

More than 200 mutations in the $O C R L$ gene have been described in Lowe syndrome patients including nonsense, splice-site, missense mutations and insertions and deletions ${ }^{10}$. The missense mutation (c. $1427 \mathrm{C}>\mathrm{T}$ ) in exon 14 of the OCRL gene observed in our patient had not been previously reported. Probably it may be a novel mutation in Sri Lanka.

\section{References}

1. Saleem MA, Tizaed J, Dudly J, Inward C, Coward R, Mc Graw M. In: Intos N, Helms P, Smyth R, Logan S, editors. Forfar and Arneils's Textbook of Paediatrics. $7^{\text {th }}$ ed. USA: Elsevier; 2008.

2. Recker F, Reutter H, Ludwig M. Lowe syndrome / Dent-2 disease: A comprehensive review of known and novel aspects. Journal of Pediatric Genetics 2013; 2:53-68. https://doi.org/10.3233/PGE-13049 PMid: 27625841 PMCid: PMC5020960

3. Loi M. Lowe syndrome. Orphanet Journal of Rare Diseases 2006; 1:16. https://doi.org/10.1186/1750-1172-1-16 PMid: 16722554 PMCid: PMC1526415

4. Amirhakimi G, Fallahzadeh MH, Saneifard H. Lowe syndrome: Report of a case and brief literature review. Iran Journal of Pediatrics 2009; 19(4):417-20. 
5. Nuwssbaum RL, Suchy SF. The metabolic and molecular basis of inherited disease. In: Scriver CR, Beaudet AL, Sly WS, Valle D, editors. $\quad 8^{\text {th }}$ ed. USA: McGraw-Hill; 2001:6257-65.

6. Takeyama K, Kitanaka S, Sato T, Kobori M, Yanagisawa J, Kato S. 25-Hydroxy vitamin D3, 1 alpha-hydroxylase and vitamin D synthesis. Science 1997; 277(5333):1827-30. https://doi.org/10.1126/science.277.5333.1827 PMid: 9295274

7. Bockenhauer D, Bokenkamp A, Hoff W, Levtchenko E, Holthe KJE, Tasic V, et al. Renal phenotype in Lowe syndrome: a selective proximal tubular dysfunction. Clinical Journal of American Society of Nephrology 2008; 3(5); 1430-6. https://doi.org/10.2215/CJN.00520108

PMid: 18480301 PMCid: PMC2518783
8. Chutorian A, Rowland LP. Lowe's syndrome. Neurology. 1966; 16(2):115-22. https://doi.org/10.1212/WNL.16.2_Part_1.115 PMid: 5948500

9. Gardner RJ, Brown N. Lowe's syndrome: identification of carriers by lens examination. American Journal of Medical Genetics 1976; 13(6):449-54.

https://doi.org/10.1136/jmg.13.6.449

10. Genetics home reference. U.S national library of Medicine [updated cited November 2013]. Available from:

https://ghr.nlm.nih.gov/condition/OCRL. 